\title{
Manurial value of byproducts of bio-diesel feed stocks on finger millet grain and dry fodder productivity
}

\section{S. Ramesh", Balakrishna Gowda**, H.B. Raghu** and B.C. Shivakumar**}

*Department of Biotechnology, College of Agriculture, Gandhi Krishi Vigana Kendra (GKVK), Bengaluru-560065 (Karnataka), INDIA

**Bio-fuel Park, Agricultural Research Station (ARS), Madenur, Hassan, Karnataka, INDIA

*Corresponding author. E-mail: ramesh_uasb@rediffmail.com

\begin{abstract}
A replicated field experiment was conducted at Agricultural Research Station (ARS), Madenur located in Hassan District, Karnataka in rainy season during 2007 to assess the manurial value of by-products of bio-diesel feed stocks-pongamia and neem oil seed cakes vis-à-vis conventional plant nutrients sources (combination of farm yard manure and inorganic fertilizers) on the grain and fodder productivity of finger millet, the staple food cereal of southern Karnataka. Grain and dry fodder productivity of finger millet crop grown using pongamia and neem seed oil cakes is comparable to that grown using conventional plant nutrient sources. Application of plant nutrients only through pongamia and neem seed oil cakes resulted in higher available soil Nitrogen, Potassium and Organic Carbon contents.
\end{abstract}

Keywords: Bio-diesel, Finger millet, Manure pongamia seed cake, Neem seed cake

\section{INTRODUCTION}

Bio-energy generated from bio-fuels constitute a sustainable and renewable energy source that may help to cope with rising energy pieces, address environmental concerns about green house gas emissions resulting from the use of fossil-derived fuels and offer new income and employment opportunities to farmers and rural communities around the world (Hazell and Pachauri, 2006). Bio-fuel is liquid form of energy generated from biomass. Bio-diesel, bio-ethanol and biomass gasification are the three major bio-energy options, which have huge potential in India to develop as potential energy sources and where investments made would be economical (Parikh and Walia 2002). Bio-ethanol is produced from any starch/cellulose/sugar-based feed stocks. Bio-diesel, which is similar in composition to fossil-diesel, is produced from oils/fats of plant/ animal origin. Bio-diesel was probably the first of the alternative fuels known to public (Bharadwaj et al., 2007). Jatropha (Jatropha curcas), Pongamia (Pongamia pinnata), Neem (Azadiricta indica), Hippe (Madhuka indica) and Simarouba (Simarouba glauca) have been identified as potential feedstock shrub/tree species for bio-diesel production. These bio-energy species yield non-edible oilseeds which are raw materials for bio-diesel production. Bio-diesel is produced by a process known as transesterification of the oils that are extracted from the oilseeds from these bio-energy species.

The likely large-scale bio-energy crop plantations for producing bio-diesel following promotional activities of the government of India as well as several state governments and increased awareness among the public about the benefits from the use of bio-fuels in goods and public transport vehicles are expected to result in the production of large quantities of by-products such as oil cakes (after oil expulsion from oilseeds). Exploring the alternative uses of these by-products, which will provide additional income, will go a long way in attracting biofuel industry, as it is the most important determinant factor for economic viability of bio-diesel production (Parikh and Walia 2002). If oils are extracted at the farmers' level, the resulting oil cakes can be recycled as valuable major and micro-nutrients sources. The utility of neem oil seed cake as a fertilizer as well as a pesticide on economically important crop species, especially on plantation crops is well established. However, the studies on the manurial value of pongamia and neem oil seed cakes on the productivity of annual crop plants, especially underutilized crops like finger millet and the long-term impact of the application of these sources of plant nutrients on soil nutrient status are scanty. Under this premise, an experiment was conducted during 2007 rainy season at Agricultural Research Station(ARS), Madenur, Hassan to assess the grain and fodder productivity of finger millet grown using the application of pongamia and neem oil seed cakes as compared to that grown using recommended practice of nutrient application (combination of farm yard manure and inorganic fertilizers). Finger millet is the staple cereal grain grown 
Table 1. Description of treatments as different combination of organic and inorganic sources of nutrients applied for raising finger millet crop at Agricultural research station, Madenur, Hassan district during 2007 rainy season.

\begin{tabular}{cl}
\hline Treatment & \multicolumn{1}{c}{ Description } \\
\hline $\mathrm{T}_{1}$ & Recommended Farm Yard Manure (FYM) + Recommended Nitrogen (N) through inorganic fertilizers \\
& (control) \\
$\mathrm{T}_{2}$ & Vermi compost @ recommended FYM + Recommended N through neem oil seed cake \\
$\mathrm{T}_{3}$ & Vermi compost @ recommended FYM + Recommended N through pongamia oil seed cake \\
$\mathrm{T}_{4}$ & Vermi compost @ recommended FYM + 50\% Recommended N through neem oil seed cake + urea top \\
& dress 30 days after sowing (DAS) \\
$\mathrm{T}_{5}$ & Vermi compost @ recommended FYM + 50\% Recommended N through pongamia oil seed cake + urea \\
& top dress (DAS) \\
$\mathrm{T}_{6}$ & Recommended FYM + recommended N through neem oil seed cake \\
$\mathrm{T}_{7}$ & Recommended FYM + recommended N through pongamia oil seed cake \\
\hline
\end{tabular}

in large area consumed in large quantities in southern Karnataka.

\section{MATERIALS AND METHODS}

A field experiment was conducted following Randomized Complete Block Design (RCBD using three replications at the experimental plots of Agricultural Research Station (ARS), Madenur located in Hassan District during 2007 rainy season. The ARS is situated at an altitude of 423.7 $\mathrm{m}$ above mean sea level and latitude of $13.00^{\circ}$ North and Longitude of $76.09^{\circ}$ East. The short duration finger millet variety, 'GPU 45' developed by All India Coordinated Small Millets Improvement Project (AICSMIP) was used as material for the experiment. The finger millet variety GPU 45 was grown using the application of different combination (treatments) of organic (pongamia and neem seed cakes, vermi-compost and farm yard manure) and inorganic sources of plant nutrients - urea (as a source of Nitrogen), single super phosphate (as a source of Phosperous) and muriate of potash (as a source of potassium) at the rates as detailed in Table 1. The seeds of finger millet variety, GPU 45 were sown with a spacing of $0.3 \mathrm{~m}$ between rows of $4 \mathrm{~m}$ length immediately after the application of different sources of nutrients. Later, seedlings were thinned to maintain $0.1 \mathrm{~m}$ between plants within a row. Each treatment consisted of 20 rows of $4 \mathrm{~m}$ length with a plot size of $24 \mathrm{~m}^{2}$. The crop was given two protective irrigations during germination and seedling establishment to ensure uniform crop stand. All other standard crop protection and production management practices were followed to raise healthy crop. The data on per plot grain yield $(\mathrm{kg})$ and sun-dried fodder yield $(\mathrm{kg})$ (after grain harvest) in all the treatments and in each replication were recorded. The replication-wise data on per plot grain yield $(\mathrm{kg})$ and dry fodder yield $(\mathrm{kg})$ was subjected to statistically analysis. Analysis of variance (ANOVA) was performed to partition the total variation in grain and dry fodder yields into those due to treatment and block effects. The ANOVA provided the test for assessing the overall effect of treatments on finger millet grain and fodder productivity.

Soil nutrient status analysis: The soil of the experimental plot is characterized as sandy clay loam with a $\mathrm{pH}$ ranging from 5.4 to 6.5. The soil is low in native organic carbon and available phosphorus contents, while adequate in available potassium contents. Soil samples were taken from the experimental plot after the harvest of the finger millet to assess the impact of application of different oil seed cakes on soil fertility in terms of major nutrients and organic matter contents. Soil samples were analyzed for different soil nutrients at Soil Science Laboratory of Krishi Vignana Kendra (KVK), Kandali, Hassan. The available soil Nitrogen (N), Phosphrous (P), and Potassium (K) contents were expressed in $\mathrm{Kg} \mathrm{ha}^{-1}$ and Organic Carbon (OC) was expressed in percentage of soil dry weight.

\section{RESULTS AND DISCUSSION}

Grain and dry fodder productivity: The ANOVA (Table 2) indicated that on an average, treatments comprising different combination of organic fertilizers such as FYM and neem and pongamia oil seed cakes and inorganic fertilizers appeared to have no significant effect on grain

Table 2. Mean sum of squares for grain and dry fodder productivity as influenced by the application of different combinations of neem and pongamia oil seed cakes.

\begin{tabular}{llcc}
\hline Source & $\begin{array}{c}\text { Degrees of } \\
\text { Freedom }\end{array}$ & $\begin{array}{c}\text { Mean sum of Squares } \\
\text { Grain yield } \\
\mathbf{( k g )} \text { plot }^{\mathbf{1}}\end{array}$ & $\begin{array}{c}\text { Dry fodder yield } \\
\mathbf{( k g )} \mathbf{~ p l o t ~}^{-1}\end{array}$ \\
\hline Treatment & 06 & 1.73 & 7.98 \\
Replication & 02 & 0.27 & 8.47 \\
Error & 12 & 1.13 & 6.34 \\
Sem \pm & - & 0.61 & 1.45 \\
\hline
\end{tabular}


Table 3. Effect of different combinations of organic fertilizers (neem and pongamia oil seed cakes) and inorganic fertilizers on grain and dry fodder productivity of finger millet at Agricultural Research Station, Madenur, Hassan during 2007 rainy season.

\begin{tabular}{|c|c|c|c|c|}
\hline Treatment & $\begin{array}{l}\text { Grain yield } \\
(\mathbf{k g}) \text { plot }^{1} \\
\left(24 \mathbf{m}^{2}\right)\end{array}$ & $\begin{array}{l}\text { \% Grain yield } \\
\text { improvement } \\
\text { over control }\end{array}$ & $\begin{array}{l}\text { Dry fodder yield } \\
(\mathrm{kg}) \mathrm{plot}^{-1} \\
\left(24 \mathrm{~m}^{2}\right) \\
\end{array}$ & $\begin{array}{l}\text { \% Dry fodder yield } \\
\text { improvement } \\
\text { over control }\end{array}$ \\
\hline Recommended $\quad$ FYM $\quad+$ & & & & \\
\hline $\begin{array}{l}\text { recommended } \mathrm{N} \text { through } \\
\text { inorganic sources (control) }\end{array}$ & 2.24 & - & 5.04 & - \\
\hline $\begin{array}{lll}\text { Vermi compost } & \text { equivalent } & \text { to } \\
\text { recommended } & \text { FYM } & +\end{array}$ & & & & \\
\hline $\begin{array}{l}\text { Recommended } \mathrm{N} \text { through neem oil } \\
\text { seed cake }\end{array}$ & 2.02 & -9.82 & 4.80 & -4.76 \\
\hline $\begin{array}{lll}\text { Vermi compost } & \text { equivalent } & \text { to } \\
\text { recommended } & \text { FYM } & +\end{array}$ & & & & \\
\hline $\begin{array}{l}\text { Recommended } \mathrm{N} \text { through pongamia } \\
\text { oil seed cake }\end{array}$ & 2.44 & 8.93 & 8.25 & 63.69 \\
\hline $\begin{array}{l}\text { Vermi compost equivalent to } \\
\text { recommended FYM }+50 \% \\
\text { recommended } \mathrm{N} \text { through neem oil } \\
\text { seed cake }+ \text { remaining } 50 \% \\
\text { recommended } \mathrm{N} \text { through urea as top } \\
\text { dress }\end{array}$ & 4.09 & 82.6 & 7.41 & 47.02 \\
\hline $\begin{array}{l}\text { Vermi compost equivalent to } \\
\text { recommended FYM }+50 \% \\
\text { recommended N through pongamia } \\
\text { oil seed cake }+ \text { remaining } 50 \%\end{array}$ & & & & \\
\hline $\begin{array}{l}\text { recommended } \mathrm{N} \text { through urea as top } \\
\text { dress }\end{array}$ & 1.73 & -22.76 & 3.88 & -23.01 \\
\hline $\begin{array}{l}\text { Recommended FYM }+100 \% \\
\text { recommended }\end{array}$ & 2.48 & 10.71 & 5.32 & 5.56 \\
\hline $\mathrm{N}$ through neem oil seed cake & & & & \\
\hline $\begin{array}{l}\text { Recommended } \mathrm{FYM}+100 \% \\
\text { recommended } \mathrm{N} \\
\text { pongamia oil seed cake }\end{array}$ & 2.66 & 18.75 & 7.23 & 43.45 \\
\hline $\operatorname{Sem} \pm$ & 0.61 & & 1.45 & \\
\hline $\mathrm{CD}(@ \mathrm{P}=0.05$ & 1.90 & - & 4.47 & - \\
\hline
\end{tabular}

and fodder yields of finger millet. However, ' $F$ ' test being less sensitive, significant differences between one or two pairs of treatments cannot be ruled out.

For example, grain yield of finger millet which received recommended FYM and neem oil seed cake equivalent to recommended $\mathrm{N}$ with $50 \%$ nitrogen as top dress after 30 days after sowing was significantly different from that received recommended FYM and inorganic sources of $100 \%$ recommended $\mathrm{N}$. It is interesting to note that application of neem and pongamia oil seed cakes equivalent to $100 \%$ recommended $\mathrm{N}$ resulted in 11 to $19 \%$ higher grain yield (though not statistically significant) (Table 3) than that obtained through the application of recommended FYM and inorganic sources of $100 \%$ NPK. Similarly application of pongamia oil seed cakes equivalent to $100 \%$ recommended $\mathrm{N}$ or neem seed oil cake equivalent to $50 \%$ recommended $\mathrm{N}+$ remaining $50 \% \mathrm{~N}$ through urea resulted in 43.45 to $63.69 \%$ higher dry fodder yield (though not statistically significant) (Table 3) than that obtained through the application of recommended FYM and inorganic sources of $100 \%$ NPK. Som et al. (1992) and Wani and Sreedevi (2005), respectively have reported significantly higher economic yields in egg plant and maize and soybean crops that received pongamia seed oil cakes compared to those that received recommended combination of inorganic fertilizers and FYM.

Soil nutrient status: ANOVA (Table 4) indicated significant differences in available soil $\mathrm{N}, \mathrm{P}$ and $\mathrm{OC}$ contents as a result of application of different sources of plant nutrients to finger millet crop. The experimental plot that received $100 \%$ recommended $\mathrm{N}$ through pongamia and neem seed cakes had numerically higher available soil $\mathrm{N}, \mathrm{K}$ and $\mathrm{OC}$ contents compared to that received recommended plant nutrient sources (control).

\section{Conclusion}

Grain and dry fodder productivity of finger millet crop grown using recommended nutrient application is comparable to that grown using nutrient application through pongamia and neem seed oil cakes. Application of nutrients only through organic sources of fertilizers such as pongamia and neem seed oil cakes will have long-term benefits in terms of building up of soil organic matter which favor multiplication of microorganisms besides improving water holding capacity. Further, organic fertilizer sources also supply micronutrients, which are highly deficient in many soils and are essential 
Table 4. Available soil nutrients status as influenced by different sources of fertilization of finger millet crop grown at Agricultural Research Station (ARS), Madenur, Hassan.

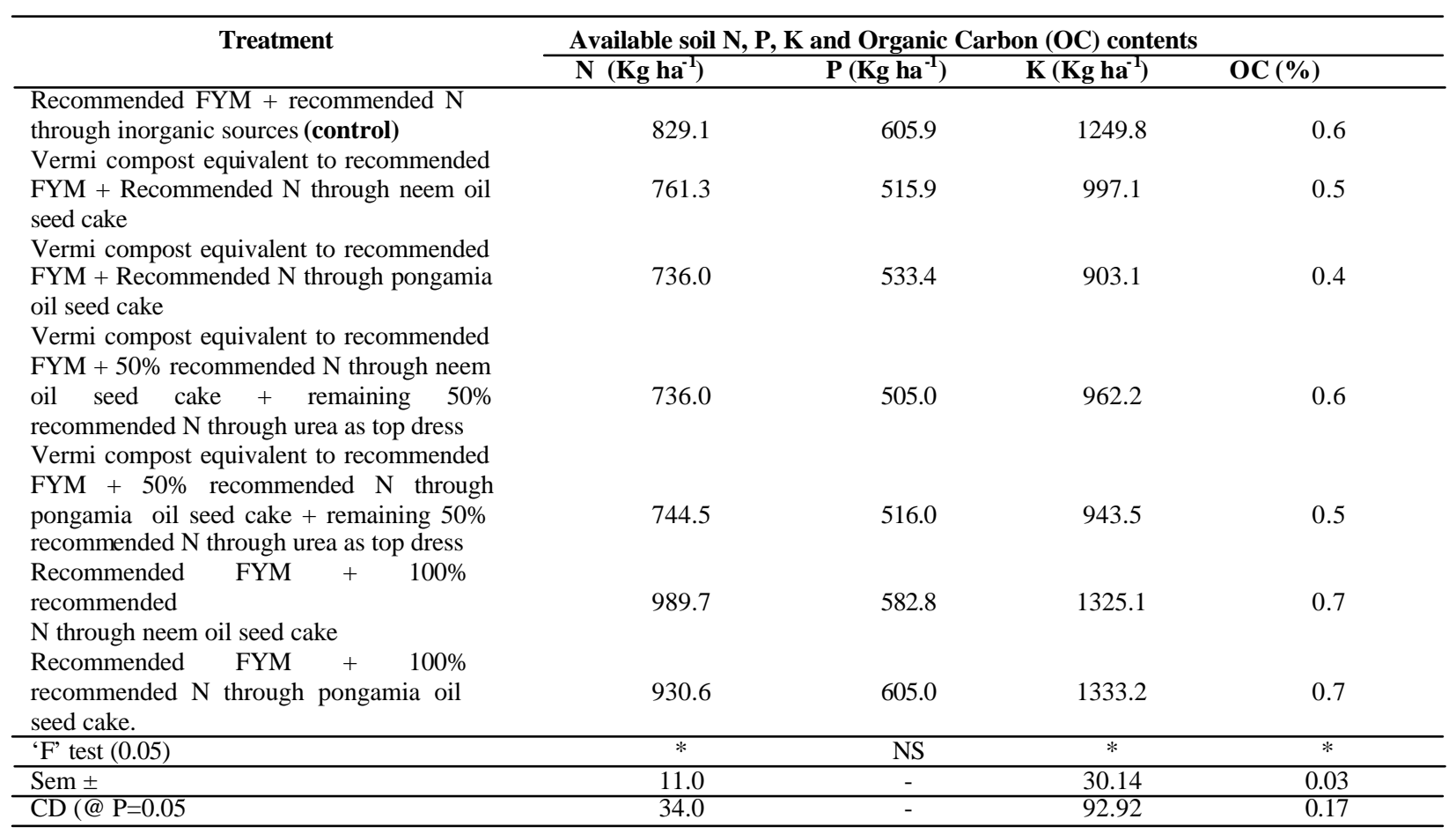

NS: Non-significant.

for optimum crop growth and yield. However, it is to be noted that the present results show certain trend and are based on single season data and hence needs confirmation through repetition of the experiments in different seasons and soil types.

\section{REFERENCES}

Bharadwaj, A., Tongia, R. and Arunachalam, V.S. (2007). Scoping technology options for India's oil security: Part Iethanol for petrol. Current Science, 92 (8):1071-1077.

Hazell, P. and Pacauri, R.K. (2006). Bio-energy and Agriculture: Promises and Challenges- an Overview. Focus 14. In: Bioenergy and Agriculture: Promises and Challenges (P. Lazell and R.K. Pachauri eds). International Food Policy Research Institute, Washington, USA and The Energy and Resources Institute, New Delhi, India.
Parikh, J. and Walia, A. (2002). Techno-economic Assessment of Bio-energy in India. Technology Information Forecasting and Assessment Council (TIFAC), Ministry of Science and Technology, Government of India, New Delhi.

Som, M.L., Hashim, H., Mandak, A.K., and Maity, T.K. (1992). Influence of organic manures on growth and yield of brinjal. Crop Research, 5(1): 80-84.

Wani, S.P., and Sreedevi, T.K. (2005). Pongamia's Journey from Forest to Micro-enterprise for Improving Livelihoods. Patancheru - 502 324, Andhra Pradesh, International Crops Research Institute for the Semi-arid Tropics. 